\title{
PENGARUH TINGKAT KEPATUHAN WAJIB PAJAK ORANG PRIBADI TERHADAP PENERIMAAN PAJAK PENGHASILAN ORANG PRIBADI PADA KPP PRATAMA CIBINONG
}

\author{
Patar Simamora \\ Dosen Tetap Fakultas Ekonomi Universitas Pakuan \\ Lecturer of Economic Faculty at Pakuan University \\ Deni Suryaman \\ Mahasiswa Fakultas Ekonomi Universitas Pakuan \\ Student of Economic Faculty at Pakuan University
}

\begin{abstract}
ABSTRAK
Pajak merupakan salah satu sumber penerimaan Negara yang digunakan untuk membiayai rumah tangga Negara dan wajib pajak orang pribadi yang telah memenuhi sebagai wajib pajak akan meningkatkan jumlah penerimaan pajak penghasilan orang pribadi, tetapi hal tersebut tidak meningkatkan penerimaan pajak penghasilan orang pribadi, apabila dalam kenyataannya tingkat kepatuhan wajib pajak orang pribadi masih dirasakan masih rendah selama ini. Adapun tujuan yang hendak dicapai adalah untuk mengetahui Pengaruh Tingkat Kepatuhan Wajib Pajak Orang Pribadi terhadap Penerimaan Pajak Pentghasilan Orang Pribadi pada KPP Pratama Cibinong. KPP Pratama Cibinong. Metode yang digunakan adalah metode analisis deskriptif yang mendefinisikan Pengaruh Tingkat Kepatuhan Wajib Pajak Orang Pribadi terhadap Penerimaan Pajak Penghasilan Orang Pribadi pada KPP Pratama Cibinong. Berdasarkan hasil penelitian yang telah dilakukan, maka penulis dapat menyimpulkan bahwa Tingkat Kepatuihan Wajib Pajak Orang Pribadi berpengaruh terhadap Penerimaan Pajak Penghasilan Orang Pribadi Pada KPP Pratama Cibinong.
\end{abstract}

Kata kunci: Tingkat Kepatuhan, NPWP Terdaftar, Penyampaian SPT , Penyetoran Pajak, Penerimaan PPh OP.

\begin{abstract}
Tax is one source of state revenue is used to finance the household of the State and individual taxpayers who have responsible as a taxpayer who will increase the number of admissions personal income tax, but it does not increase the acceptance of personal income tax, when in reality the level of compliance individual taxpayers still perceived remains low during this time. The goals to be achieved is to determine the Effect of Individual Taxpayer Compliance on the Personal Income Tax Revenue on KPP Pratama Cibinong. The method I use is descriptive analysis method which defines Effect of Individual Taxpayer Compliance to the Personal Income Tax Revenue on KPP Pratama Cibinong. Based on the research that has been done, the writer can conclude that the level of the individual taxpayer Kepatuihan effect on Personal Income Tax Revenue In KPP Pratama Cibinong.
\end{abstract}

Keywords: Level of Compliance, TIN Registered, submission of tax returns, Payment of Tax, Tax Receipts $O P$.

\section{Pendahuluan}

Pajak merupakan salah satu sumber penerimaan Negara yang digunakan untuk membiayai rumah tangga Negara, yakni pengeluaranpengeluaran yang bermanfaat bagi masyarakat luas. Semakin besarnya pengeluaran pemerintah menuntut peningkatan penerimaan Negara, dimana yang diharapkan berasal dari dalam negeri, tanpa harus bergantung pada bantuan dan pinjaman. Hal ini yang menjadikan Direktorat Jenderal Pajak melakukan segala upaya untuk memaksimalkan penerimaan pajak.

Pemungutan Pajak di Indonesia mengacu pada Self assessment system. Dalam praktiknya sulit dijalankan sesuai 
harapan, bahkan sering disalah gunakan oleh wajib pajak. Terbukti dari wajib pajak yang dengan sengaja tidak patuh, sehingga wajib pajak yang lain enggan dalam memenuhi kewajiban perpajakannya. Isu kepatuhan perpajakan sendiri menjadi penting karena secara bersamaan akan menimbulkan upaya penghindaran pajak yang mengakibatkan berkurangnya penyetoran pajak pada Kas Negara.

Tabel 1.1.

Ringkasan Rasio Kepatuhan WP OP dalam menyampaikan SPT dan

Realisasi PPh OP pada tahun 2008-2011

Summary of Compliance Ratio WP OP to extended SPT and

Realization PPh OP period 2008 - 2011

\begin{tabular}{|c|c|c|c|c|c|}
\hline Tahun & $\begin{array}{c}\text { WPOP } \\
\text { Terdaftar }\end{array}$ & $\begin{array}{c}\text { WPOP } \\
\text { Efektif }\end{array}$ & $\begin{array}{c}\text { SPT } \\
\text { PPhOP }\end{array}$ & $\begin{array}{c}\text { Rasio Kepatuhan } \\
\text { WP OP dalam } \\
\text { menyampaikan } \\
\text { SPT }(\%)\end{array}$ & $\begin{array}{c}\text { Realisasi PPH OP } \\
(\mathrm{Rp})\end{array}$ \\
\hline 2008 & 70.422 & 65.815 & 41.790 & 63.50 & 6.647 .047 .999 \\
\hline 2009 & 126.402 & 116.947 & 60.769 & 51.96 & 5.249 .600 .862 \\
\hline 2010 & 150.960 & 140.571 & 63.462 & 45.15 & 4.272 .571 .896 \\
\hline 2011 & 173.165 & 162.206 & 67.119 & 41.38 & 5.608 .338 .153 \\
\hline
\end{tabular}

Sumber: Data diolah

Penurunan rasio kepatuhan wajib pajak orang pribadi harus diperhatikan dengan seksama. Realisasi penerimaan pajak penghasilan orang pribadi bisa lebih tinggi lagi, apabila seluruh wajib pajak orang pribadi terdaftar efektif melakukan kewajiban menyetorkan pajaknya. Adapun tujuan yang hendak dicapai oleh penulis adalah sebagai berikut:

1. Untuk mengetahui tingkat kepatuhan wajib pajak orang pribadi di KPP Pratama Cibinong.

2. Untuk mengetahui realisasi penerimaan pajak penghasilan orang pribadi.

3. Untuk mengetahui pengaruh tingkat kepatuhan wajib pajak orang pribadi terhadap penerimaan pajak penghasilan orang pribadi.

\section{Metode Penelitian}

Penelitian ini dilakukan dengan menggunaan metode analisis Deskriptif Kuantitatif dengan menggunakan Statistik Parametrik, untuk menganalisis variabel terikat dan variabel bebas dengan hubungan sebab akibat (causal).

\section{Hasil dan Pembahasan}

1. Tingkat Kepatuhan Wajib Pajak Orang Pribadi

Dalam mengukur kepatuhan wajib pajak orang pribadi pasal 21/26 di wilayah cakupan KPP Pratama Cibinong selama tiga tahun dari tahun 2009 sampai tahun 2011, dapat diketahui dengan menghitung Rasio kepatuhan dalam menyampaikan SPT yang disampaikan oleh Wajib Pajak Orang Pribadi dan ketepatan waktu dalam menyampaikan SPT serta menyetorkan pajak dan kebenaran dalam menyetorkan 
pajak. Adapun rumus yang digunakan, sebagai berikut:

Rasio kepatuhan dalam menyampaikan SPT $=\frac{\text { jumlah SPT yang disampaikan }}{\text { jumlah WP OP efektif }} \times 100 \%$ Tepat waktu dalam menyampaikan SPT $=\frac{\text { jumlah SPT disampaikan tepat waktu }}{\text { jumlah SPT yang disampaikan }} \times 100 \%$ Tepat waktu dalam menyetorkan pajak $=\frac{\text { jumlah SSP disetorkan tepat waktu }}{\text { jumlah SSP yang disetorkan }} \times 100 \%$ Benar dalam menyetorkan pajak $=\frac{\text { jumlah SSP yang Benar }}{\text { jumlah SSP yang disetorkan }} \times 100 \%$

Berdasarkan Ringkasan Tingkat Kepatuhan Wajib Pajak Orang Pribadi pada KPP Pratama Cibinong maka dapat diketahui tingkat kepatuhan wajib pajak orang pribadi dengan klasifikasi yangtberbeda, dimana setiap klasifikasi tingkat kepatuhan dapat berbeda beda atau sama. Berdasarkan tabel 2 menunjukan tingkat kepatuhan yang sangat rendah dibandingkan dengan target kepatuhan penyampaian surat pemberitahuan berdasarkan Surat Edaran Direktur Jenderal Pajak Nomor SE18/PJ/2011, dimana target minimal rasio kepatuhan wajib pajak dalam penyampaian surat pemberitahuan untuk willayah KPP Pratama Cibinong sebesar $67,50 \%$. Rasio kepatuhan dalam menyampaikan SPT tertinggi terdapat pada bulan januari pada tahun 2009 dengan jumlah rasio kepatuhan dalam menyampaikan SPT sebesar 21,75\%. Sedangkan rasio kepatuhan dalam menyampaikan SPT paling rendah terdapat pada bulan Juli tahun 2011 dengan jumlah rasio kepatuhan dalam menyampaikan SPT sebesar $11,41 \%$.

2. Penerimaan Pajak Penghasilan Orang Pribadi
Salah satu tujuan utama dari pelaksanaan kegiatan pada KPP Pratama Cibinong pada wajib pajak orang pribadi adalah memenuhi target penerimaan pajak penghasilan orang pribadi setiap priode pajak, sehingga jumlah penerimaan yang didapat akan mencapai rencana yang telah ditentukan. Berikut data perkembangan rencana penerimaan pajak penghasilan orang pribadi pada KPP Pratama Cibinong pada tahun 2009 s/d 2011.

Realisasi penerimaan pajak penghasilan yang diterima belum tentu sesuai dengan target penerimaan pajak penghasilan yang telah ditentukan pada priode masa pajak PPh Pasal 21/26 wajib pajak orang pribadi.

Berdasarkan Perkembangan Rencana dan Realisasi Penerimaan PPh Pasal 21/26 WP OP pada KPP Pratama Cibinong bahwa pencapaian penerimaan PPh Pasal 21/26 wajib pajak orang pribadi jarang berhasil mencapai target yang telah ditentukan, Akan tetapi pada bulan Februari tahun 2010 penerimaan PPh Pasal 21/26 melewati target penerimaan PPh Pasal 21/26 wajib pajak orang pribadi dengan persentase 102,31\%. Realisasi penerimaan $\mathrm{PPh}$ 
Pasal 21/26 pada bulan November dan Desember pada tahun 2011 target peerimaan $\mathrm{PPh}$ Pasal 21/26 wajib pajak orang pribadi terlampaui, dengan persentase $105,29 \%$ pada bulan November tahun 2011 dan 103,53\% pada bulan Desember tahun 2011.

3. Pengaruh Tingkat Kepatuhan Wajib Pajak Orang Pribadi Terhadap PPh Wajib Pajak Orang Priabadi

Uji Hipotesis Simultan atau uji hipotesis secara bersama-sama digunakan untuk mengetahui bersamasama apakah secara silmultan variabel bebas tingkat kepatuhan wajib pajak orang pribadi yang terdiri dari rasio tingkat kepatuhan dalam menyampaikan SPT (X1), tepat waktu dalam menyampaikan SPT (X2), tepat waktu dalam menyetorkan pajak (X3), dan benar dalam menyetorkan pajak (X4) memiliki hubungan yang signifikan dengan variabel dependen penerimaan pajak penghasilan wajib pajak orang pribadi (Y), maka dapat dilakukan uji signifikansi dengan hipotesis:

HO : Tidak terdapat pengaruh pada tingkat kepatuhan wajib pajak orang pribadi terhadap penerimaan pajak penghasilan orang pribadi pada KPP Pratama Cibinong.

$\mathrm{Ha}$ : Terdapat pengaruh pada tingkat kepatuhan wajib pajak orang pribadi terhadap penerimaan pajak penghasilan orang pribadi pada KPP Pratama Cibinong.

Berdasarkan tabel Uji Koefisien Regresi Secara Simultan (Uji F) menunjukkan bahwa nilai sig $0,000 \leq$ 0,05 maka H0 ditolak dan Ha diterima dan menjelaskan tingkat kepatuhan wajib pajak orang pribadi (X) berpengaruh secara positif terhadap penerimaan pajak penghasilan orang pribadi (Y). Pada tabel 16 juga diperoleh nilai $F_{\text {hitung }}$ pada kolom $F$ sebesar 52,556 dengan menggunakan tingkat keyakinan $95 \%, \alpha=5 \%$, df 1 (jumlah variabel-1) atau 5-1=4 dan df $2=31$, maka didapat $F_{\text {tabel }}$ sebesar 2,641 . Kriteria dalam pengujian $\mathrm{F}$ yaitu:

- $\quad$ Ho diterima bila $\mathrm{F}_{\text {hitung }} \leq \mathrm{F}_{\text {tabel }}$

Ho ditolak bila $\mathrm{F}_{\text {hitung }}>\mathrm{F}_{\text {tabel }}$

Dengan kriteria tersebut diperoleh nilai 52,556 $>2,641$ atau $\mathrm{F}_{\text {hitung }}>\mathrm{F}_{\text {tabel, }}$, maka H0 ditolak dan dapat disimpulkan bahwa secara bersama-sama ada pengaruh positif antara Tingkat Kepatuhan Wajib Pajak Orang Pribadi yang terdiri rasio tingkat kepatuhan dalam menyampaikan SPT (X1), tepat waktu dalam menyampaikan SPT (X2), tepat waktu dalam menyetorkan pajak (X3), dan benar dalam menyetorkan pajak (X4) terhadap variable terikat Penerimaan Pajak Penghasilan Wajib Pajak Orang Pribadi (Y).

Untuk mengetahui persentase sumbangan pengaruh dari Tingkat Kepatuhan Wajib Pajak Orang Pribadi (X) terhadap Penerimaan Pajak Penghasilan Wajib Pajak Orang Pribadi (Y) digunakan Koefisien determinasi. Pengujian koefisien determinasi dapat dilihat pada tabel 17 berikut ini.

Berdasarkan Koefisien determinasi dari hasil perhitungan didapat sebesar $87,1 \%$. Hal ini menunjukkan bahwa tingkat kepatuhan wajib pajak orang pribadi memberikan pengaruh sebesar $87,1 \%$ artinya (sangat berpengaruh) terhadap penerimaan pajak penghasila pasal 21/26 wajib pajak orang pribadi pada kantor Pelayanan Pajak Pratama Cibinong, sedangkan sisanya sebesar 12,9 penerimaan pajak penghasilan pasal $21 / 26$ wajib pajak orang pribadi pada KPP Pratama Cibinong dapat dijelaskan oleh variabel lainnya yang tidak diteliti. Dari hasil semua perhitungan diatas, maka dapat disimpulkan bahwa tingkat kepatuhan wajib pajak orang pribadi mempunyai korelasi yang sangat kuat 
terhadap penerimaan pajak penghasilan pasal 21/26 wajib pajak orang pribadi, ditunjukkan oleh angka hasil korelasi yaitu sebesar 0,934. Meskipun bukan satu-satunya faktor yang mempengaruhi penerimaan pajak penghasilan pasal 21/26 wajib pajak orang pribadi, tapi tingkat kepatuhan pajak adalah faktor terkuat dari beberapa faktor yang mempengaruhi penerimaan pajak penghasilan wajib pajak orang pribadi karena pengaruh yang diberikan oleh tingkat kepatuhan wajib pajak lebih dari $75 \%$ yaitu $87,1 \%$ sehingga tingkat kepatuhan wajib pajak merupakan faktor utama bila dibandingkan dengan faktor lain.

Untuk mengetahui apakah dalam model regresi pemeriksaan pajak (X) berpengaruh signifikan terhadap tingkat Kepatuhan Wajib Pajak Orang Pribadi (Y) selain menggunakan uji hipotesis simulan dapat digunakan juga uji hipotesis secara parsial. Uji hipotesis parsial untuk menguji hubungan antara masing-masing variabel bebas terhadap variabel terikat secara parsial atau per variabel dengan kriteria pengujian:

- $\quad$ Ho diterima jika $-t_{\text {tabel }} \leq t_{\text {hitung }} \leq$ $t_{\text {tabel }}$

- $\quad$ Ho ditolak jika $-t_{\text {hitung }}<-t_{\text {tabel }}$ atau $t_{\text {hitung }}>t_{\text {tabel }}$

Berdasarkan tabel Uji Koefisien Regresi Secara Parsial (Uji t) diperoleh t hitung untuk Rasio Kepatuhan dalam menyampaikan SPT sebesar -0,436 dengan signifikasi (sig) 0,666 sedangkan untuk Ketepatan waktu dalam menyampaika SPT sebesar 6,590 dengan signifikasi (sig) 0,000 untuk Ketepatan waktu dalam menyetorkan pajak sebesar -5,504 dengan signifikasi (sig) 0,000 dan nilai $\mathrm{t}$ untuk Benar dalam menyetorkan pajak sebesar -2,949 dengan tingkat signifikansi (sig) 0,006. Untuk mencari t tabel dicari menggunakan uji 1 (satu) sisi pada tingkat signifikansi yaitu $\alpha=$
0,05 dengan derajat kebebasan (df) n-1 atau 36-1 = 35 ( $\mathrm{n}$ adalah jumlah kasus) maka diperoleh $\mathrm{t}$ tabel sebesar 2,030.

Dengan demikian secara parsial koefisien regresi yang mewakili tingkat kepatuhan wajib pajak orang pribadi tidak seluruhnya berpengaruh pada penerimaan pajak penghasilan wajib pajak orang pribadi pada KPP Pratama Cibinong, dapat diketahui dari uji hipotensis parsial, dimana Rasio Kepatuhan dalam Menyampaikan SPT (X1) secara parsial tidak berpengaruh terhadap penerimaan pajak penghasilan wajib pajak orang pribadi pada KPP Pratama Cibinong. Salah satu kemungkinan bahwa penerimaan Pajak Penghasilan Wajib Pajak Orang Pribadi pada KPP Pratama Cibinong yang lebih disebabkan oleh besarnya pajak terutang yang disetorkan oleh wajib pajak orang pribadi, menjadi salah satu penyebab Rasio Kepatuhan dalam Menyampaikan SPT (X1) tidak berpengaruh terhadap Penerimaan Pajak Penghasilan Wajib Pajak Orang Pribadi pada KPP Pratama Cibinong.

Untuk koefisien regresi Tepat Waktu dalam Menyampaikan SPT (X2), Tepat Waktu dalam Menyetorkan Pajak (X3), dan Benar dalam Menyetorkan Pajak (X4) secara parsial memiliki pengaruh terhadap Penerimaan Pajak Penghasilan Wajib Pajak Orang Pribadi pada KPP Pratama Cibinong. Koefisien regresi Tepat Waktu dalam Menyampaikan SPT (X2), Tepat Waktu dalam Menyetorkan Pajak (X3), dan Benar dalam Menyetorkan Pajak (X4) berpengaruh terhadap penerimaan pajak penghasilan wajib pajak orang pribadi menandakan tolak ukur terhadap tingkat kepatuhan wajib pajak orang pribadi dalam keadaan dan kondisi wilayah jangkawan KPP Pratama Cibinong, mengakibatkan Koefisien regresi Tepat Waktu dalam Menyampaikan SPT (X2), Tepat Waktu dalam Menyetorkan Pajak 
(X3), dan Benar dalam Menyetorkan Pajak (X4) dapat berpengaruh positif terhadap penerimaan pajak penghasilan wajib pajak orang pribadi.

\section{Kesimpulan}

Berdasarkan hasil penelitian mengenai Pengaruh Tingkat Kepatuhan Wajib Pajak Orang Pribadi terhadap Penerimaan Pajak Penghasilan Orang Pribadi pada Kantor Pelayanan Pajak Pratama Cibinong, dapat disimpulkan:

1. Tingkat Kepatuhan Wajib Pajak Orang Pribadi pada KPP Pratama Cibinong. Dapat disimpulkan bahwa tingkat kepatuhan wajib pajak orang pribadi pada KPP Pratama Cibinong masih kurang bila dilihat dari tingkat kepatuhan wajib pajak orang pribadi dalam menyampaikan SPT dan benardalam menyetorkan pajak terutangnya. Sedangkan dilihat dari ketepatan waktu dalam menyampaikan dan menyetorkan SPT, tingkat kepatuhan wajib pajak orang pribadi sangat tinggi. Hal tersebut membuktikan juga bahwa wajib pajak orang pribadi lebih memperhatikan ketepatan waktu dalam kewajiban perpajakannya dibandingkan kebenaran dalam menyetorkan pajak terutangnya.

2. Penerimaan Pajak Penghasilan Wajib Pajak orang Pribadi pada KPP Pratama Cibinong. Dapat disimpulkan bahwa KPP Pratama Cibinong belum mampu memenuhi atau mencapai rencana penerimaan pajak penghasilan yang telah ditentukan oleh Kantor Wilayah Jawa Barat II (Kanwil Jabar II) secara terus menerus.

3. Pengaruh Tingkat Kepatuhan Wajib Pajak Orang Pribadi terhadap Penerimaan Pajak Penghasilan Wajib Pajak Orang
Pribadi Pada KPP Pratama Cibinong. Berdasarkan Uji Hipotesis yang dilakukan mengenai pengaruh tingkat kepatuhan wajib pajak orang pribadi terhadap penerimaan pajak penghasilan wajib pajak orang pribadi pada KPP Pratama Cibinong, yaitu Uji Koefisien Determinasi dan Uji Koefisien Regresi secara Simultan (Uji F) maka diperoleh hasil bahwa tingkat kepatuhan wajib pajak orang pribadi berpengaruh terhadap penerimaan pajak penghasilan wajib pajak orang pribadi pada KPP Pratama Cibinong. Sedangkan pada Uji Koefisien Regresi secara Parsial (Uji T), tidak seluruhnya koefisien regresi yang diuji tidak seluruhnya mempengaruhi variabel dependen, dibandingkan dengan koefisien regresi Tepat Waktu dalam Menyampaikan SPT (X2), Tepat Waktu dalam Menyetorkan Pajak (X3), dan Benar dalam Menyetorkan Pajak (X4) secara parsial memiliki pengaruh terhadap Penerimaan Pajak Penghasilan Wajib Pajak Orang Pribadi pada KPP Pratama Cibinong.

\section{Daftar Pustaka}

Diana Anastasia. 2010. Perpajakan Indonesia. Edisi 3. Salemba ANDI, Yogyakarta.

Priyanto, Duwi. 2012. Cara Kilat Belajar Analisis Data Dengan SPSS. ANDI, Yogyakarta.

Simanjuntak, Timbul. H., dan Imam Mukhlis. 2012. DIMENSI EKONOMI PERPAJAKAN DALAM PEMBANGUNA EKONOMI. Raih Asa Sukses, Bogor. 
Soewanji, Jusuf. 2012. Pengantar Metodologo Penelitian. Mitra Wacana Media, Jakarta.

Suhartono Rudi, Wirawan. 2010. Eknsiklopedia Perpajakan Indonesia. Salemba Empat, Jakarta.

Surat Edaran Direktorat Jenderal Pajak Nomor SE-18/PJ/2012 tentang Target Rasio Kepatuhan Penyampaian Surat Pemberitahuan Pada Tahun 2011.

Thomas Sumarsan. 2012. Perpajakan Indonesia. Indeks, Jakarta.

Widodo Widi., Dkk. 2010. Moralitas, Budaya dan Kepatuhan Pajak. ALFABETA, Bandung.

Yamin Mohammad. 2012. PAJAK PENGHASILAN. Graham Ilmu, Yogyakarta. 